\title{
The effects of dexamethasone on the proliferation and apoptosis of human ovarian cancer cells induced by paclitaxel
}

\author{
Wenjing Hou, Jianhua Guan, Huan Lu, Qian Dong, Yuhong Han and Rong Zhang*
}

\begin{abstract}
Background: Dexamethasone (DEX) has been routinely used as a pre-treatment in the clinical application of paclitaxel (PTX) to treat ovarian cancer. However, PTX-induced apoptosis might be inhibited by DEX. This study was undertaken to investigate the effects of DEX on the apoptosis induced by PTX.

Methods: Both of SKOV-3 and HO-8910 human ovarian cancer cells were divided into four groups: (1) untreated (Con); (2) treated with DEX (0.1 $\mu \mathrm{M})$ alone; (3) treated with PTX (50 nM); and (4) pre-treated with DEX (0.1 $\mu \mathrm{M})$, and $24 \mathrm{~h}$ later, treated with PTX (DEX + PTX). Cell proliferation was determined by the 3-(4,5)-dimethylthiahiazo (-z-y1)-3,5-di- phenytetrazoliumromide (MTT) dye uptake method, while cell apoptosis was analyzed by propidium iodide (PI) staining and flow cytometry. Then, reverse transcription polymerase chain reactions (RT-PCRs) were applied to semi-quantitative analysis, followed by western blot analysis. Statistical analysis was performed, with Fisher's least significant difference test.
\end{abstract}

Results: Our results demonstrated that DEX can differentially inhibit SKOV-3 and HO-8910 cell proliferation induced by PTX and decrease the apoptosis rates in cancer cells. Pre-treatment with DEX could up-regulate the expressions of members of anti-apoptotic $\mathrm{BCl}-2$ family (BCl-2 and $\mathrm{BCl}-\mathrm{XL}$ ) and members of IAP family (survivin). The expression of cleaved caspase-3 was down-regulated by DEX, shown by semi-quantitative RT-PCRs and western blot analysis.

Conclusions: Our data gained invaluable insights of the antagonistic mechanisms of DEX on PTX-induced cancer cell death and may provide new methods of using DEX as antineoplastic drugs or agents in the clinical treatment for ovarian cancer patients.

Keywords: BCI-XL, Cleaved caspase-3, Dexamethasone, Ovarian cancer, Paclitaxel, Survivin

\section{Introduction}

Ovarian cancer has the poorest prognosis of all gynecological cancers and is a leading cause of death in women with cancers [1,2]. Recently, new chemotherapeutic agents, including taxanes, gemcitabine and irinotecan, have become clinically available to treat ovarian cancer. Among these newer drugs, paclitaxel (PTX) is the one used most frequently for the treatment of patients with ovarian cancer, especially the advanced ovarian cancer.

The exact mechanism of cell death induced by PTX is elusive, though it is widely known that the major cellular

\footnotetext{
* Correspondence: rongzhangrz@hotmail.com

Department of Obstetrics and Gynecology, Shanghai Jiaotong

University-Affiliated Sixth People's Hospital of Fengxian Branch, 6600 Nanfeng Road, Shanghai 201499, People's Republic of China
}

target of PTX is the tubulin/microtubule system in mitosis [3]. Dexamethasone (DEX) is routinely used as a pre-treatment in the clinical application of PTX to prevent hypersensitivity reactions and other adverse effects such as nausea, emesis and toxic reactions [4-6].

However, recent studies have discovered that DEX selectively inhibits PTX-induced apoptosis in a number of carcinoma cell lines, including ovary, breast, testis, prostate, bladder, pancreas, kidney, liver, colon, brain, cervix, bone and skin [7-14]. The inhibition of PTXinduced apoptosis by DEX may occur through enhancing DNA repair capacity, suppressing host antitumor immune responses or blocking apoptosis $[15,16]$. The apoptosis of cancer cell may be antagonized by anti-apoptotic modulator proteins, such as survivin (a member of the IAP family), 
$\mathrm{Bcl}-2$ and $\mathrm{Bcl}-\mathrm{XL}$ (members of the Bcl-2 family). The death receptor and mitochondrial death pathways may be linked by Bcl-XL, which subsequently activates the proteolytic activation of effector caspases-3 to trigger the mitochondrial dysfunction and cytochrome c release [17-19]. Also, DEX pre-treatment has been recently reported to interfere with apoptotic death in brain tumour cells by the transcriptional activation of a Bcl-XL gene [20-26].

To determine whether DEX would inhibit PTX-induced apoptosis in ovarian cancer cells and reduce the therapeutic efficacy of PTX, we performed in vitro experiments with the human ovarian cancer SKOV-3 and HO-8910 cell lines to evaluate the effects and mechanisms of DEX on human ovarian cancer cell apoptosis induced by PTX. Surprisingly, DEX had a strong anti-apoptotic effect on the carcinoma cells and prevented PTX-induced cancer cell reduction and apoptosis. This result was due to the inhibition of key molecules of death receptor and mitochondrial apoptosis pathway, resulting in a blockade of caspase activity. The direct transfer of caspases restored the apoptosis sensitivity of DEX-treated carcinomas in vitro. These findings suggest that the pro-apoptotic effects of chemotherapy regimens in patients with ovarian cancer might be strongly antagonized by the anti-apoptotic effects of DEX.

\section{Materials and methods}

\section{Cell culture and group}

SKOV-3 and HO-8910 human ovarian cancer cells were obtained from Shanghai Cancer Institute, and cultured in RPMI-1640 (Invitrogen, Carlsbad, CA) supplemented with $10 \%$ fetal bovine serum (Sigma Chemical Co., St. Louis, $\mathrm{MO}$ ) and $1 \%$ penicillin and streptomycin (Sigma Chemical Co., St. Louis, $\mathrm{MO}$ ) in a $5 \% \mathrm{CO}_{2}$ and $37^{\circ} \mathrm{C}$ incubator. DEX (Sigma Chemical Co., St. Louis, MO) was dissolved in ethanol before added to culture medium. The final ethanol concentration was $0.1 \%$. PTX (Sigma Chemical Co., St. Louis, MO) was dissolved in PBS (PH 7.4, Sigma Chemical Co., St. Louis, MO) with a concentration of $1 \mu \mathrm{M}$.

The SKOV-3 and HO-8910 cells were divided into four groups: (1) untreated (Con); (2) treated with DEX $(0.1 \mu \mathrm{M})$ alone; (3) treated with PTX (50 nM); and (4) pre-treated with DEX $(0.1 \mu \mathrm{M})$, and $24 \mathrm{~h}$ later, treated with PTX (DEX + PTX).

\section{Cell proliferation assay}

The proliferation of SKOV-3 and HO-8910 were determined by the 3-(4,5)-dimethylthiahiazo (-z-y1)-3,5-di- phenytetrazoliumromide (MTT) dye uptake method. Briefly, cells $(10,000 /$ well $)$ were incubated in triplicate in a 96-well plate in a final volume of $0.1 \mathrm{~mL}$ for the indicated time periods at $37^{\circ} \mathrm{C}$. Then, $0.025 \mathrm{~mL}$ of MTT solution $(5 \mathrm{mg} / \mathrm{mL}$ in PBS) was added to each well. After $2 \mathrm{~h}$ incubation at $37^{\circ} \mathrm{C}, 0.1 \mathrm{~mL}$ dimethylformamide (Sigma Chemical Co., St. Louis, MO) was added, incubation was continued for $30 \mathrm{~min}$ at $37^{\circ} \mathrm{C}$, and then the O.D. value was measured using a Bio-Rad (Model 550) microplate reader at $570 \mathrm{~nm}$, take dimethylformamide as the blank.

\section{Propidium lodide (PI) staining by flow cytometry}

Four groups of cells were harvested and centrifuged at $1,000 \mathrm{rpm}$ for $5 \mathrm{~min}$ and then fixed in $5 \mathrm{~mL} 70 \%$ prerefrigerated ethanol for $24 \mathrm{~h}$ at $-20^{\circ} \mathrm{C}$. After washing the cells with $10 \mu \mathrm{L}$ PBS twice, $1 \mathrm{mg} / \mathrm{mL}$ RNase (Sigma Chemical Co., St. Louis, MO) was added and incubated for $30 \mathrm{~min}$ at $37^{\circ} \mathrm{C}$. Then, cells were stained with $300 \mu \mathrm{L} / 50 \mu \mathrm{g} / \mathrm{mL}$ PI (Sigma Chemical Co., St. Louis, MO) in the dark for $30 \mathrm{~min}$ at $4^{\circ} \mathrm{C}$. Cell apoptosis was analyzed by flow cytometry (FCM, FACScan, Becton, Dickinson and Company, Franklin Lakes, NJ, USA).

\section{Apoptosis assay}

Four groups of cells were collected and washed twice with PBS. Cells were centrifuged at 1,000 rpm for $5 \mathrm{~min}$ and then were resuspended in reaction buffer $(200 \mu \mathrm{L}$ HEPES (2-[4-(2-Hydroxyethyl)-1-piperazinyl] ethanesulfonic acid, Sigma Chemical Co., St. Louis, MO) buffer, $1 \mu \mathrm{L}$ fluorescein isothiocyanate-labeled annexin $\mathrm{V}$ (annexin V-FITC), $2 \mu \mathrm{L} / 50 \mu \mathrm{g} / \mathrm{mL}$ PI, ApoAlert Annexin V-FITC Apoptosis Kit, CLONTECH) and incubated in dark for $10 \mathrm{~min}$ at room temperature. After $1 \mathrm{~h}$, cell apoptosis was analyzed by flow cytometry.

\section{Semi-quantitative analysis}

To semi-quantify the mRNAs of survivin, Bcl-2, and $\mathrm{Bcl}-\mathrm{XL}$, reverse transcription polymerase chain reactions (RT-PCRs) were performed. Cells were washed with icecold PBS once, and total RNA was isolated with TRIzol (Invitrogen Life Technologies, San Diego, CA), according to the instructions of the manufacturer. Approximately $2 \mu \mathrm{g}$ RNA was treated with ribonuclease-free deoxyribonuclease, and cDNA was synthesized by using Moloney murine leukemia virus reverse transcriptase (Invitrogen Life Technologies, Carlsbad, CA), and $2 \mu \mathrm{L}$ of synthesized cDNA was subjected to 30 cycles of PCR that resulted in a single specific amplification product of the expected size. The PCR conditions were as follows: $30 \mathrm{sec}$ denaturation at $94^{\circ} \mathrm{C}, 1 \mathrm{~min}$ annealing at $55^{\circ} \mathrm{C}$, and $45 \mathrm{sec}$ extension at $72^{\circ} \mathrm{C}$. PCR primers used in this study were as follows: survivin, sense $5^{\prime}$-TTGGCAGGTGCCTGTTGAAT-3' and antisense $5^{\prime}$-AGCCAGTCCCCCACAGCAT-3'; Bcl-2, sense 5'-GTGGAGGAGCSTCTTCAGGGA-3' and anti-

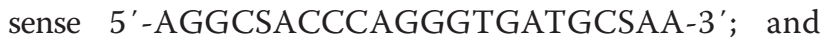
Bcl-XL, sense 5' -TTGGACAATGGACTGGTTGA-3' and antisense 5'-GTAGAGTGGATGGTCAGTG-3'. Glyceraldehyde-3-phosphate dehydrogenase (GAPDH) was used as an internal control of the PCR. The primers for GAPDH were sense 5'-GGATTTGGTCGTATTGGG-3' and antisense 5' -GGAAGATGGTGATGGGATT-3'. 


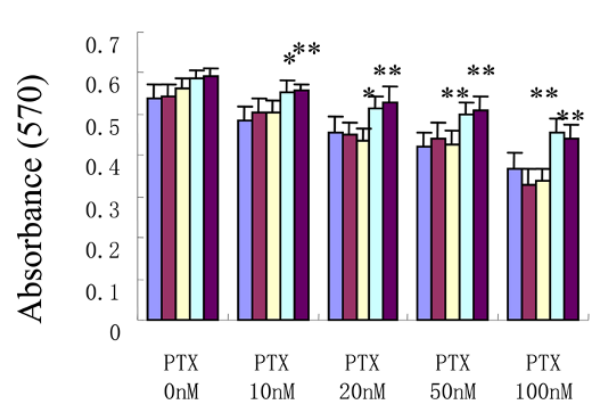

SKOV-3

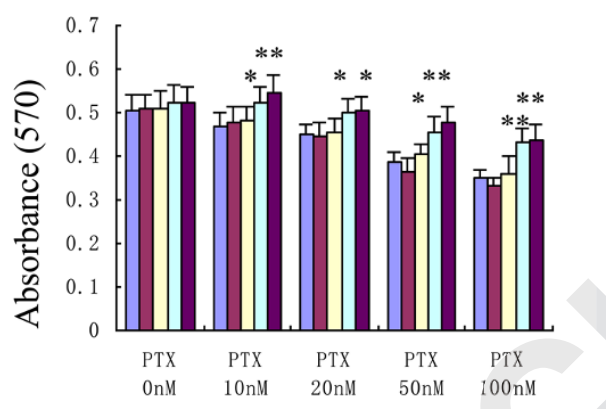

HO- 8910

Figure 1 DEX induces the proliferation of PTX-induced SKOV-3 and HO-8910 cells. SKOV-3 and HO-8910 cells were cultured in a concentration of $10^{4} / \mathrm{mL}$ either in the absence or presence of DEX for $24 \mathrm{~h}$. Then, cells of every concentration of DEX were further incubated with or without PTX for $48 \mathrm{~h}$, after which proliferation was monitored by MTT assay. Experiments were performed three times. Data were shown as mean \pm SD and compared with DEX $0 \mathrm{nM}$ (Control). *: $\mathrm{p}<0.05$; **: $\mathrm{p}<0.01$. PTX: paclitaxel; DEX: dexamethasone.

To determine the specificity of RT-PCRs, we performed the amplifications three times and took the mean value of these three reactions. The RT-PCRs were in the linear range of amplification for the target mRNA, as well as for the control. Each RT-PCR product was demonstrated on 1.4\% agarose gel stained with ethidium bromide (Sigma Chemical Co., St. Louis, MO). The bands were documented, scanned, and quantified using Quantity One software (PDI, New York, NY) and normalized with internal control (GAPDH).

\section{Western blot analysis}

Cells were lysed in ice-cold lysis buffer (10 mM Tris (tris (hydroxymethyl) aminomethane, $\mathrm{pH} 7.5$ ), $0.1 \mathrm{~nm}$ EDTA (Ethylene Diamine Tetraacetic Acid), 0.1 nM EGTA (Ethylene Glycol Tetraacetic Acid), 0.5\% SDS (Sodium

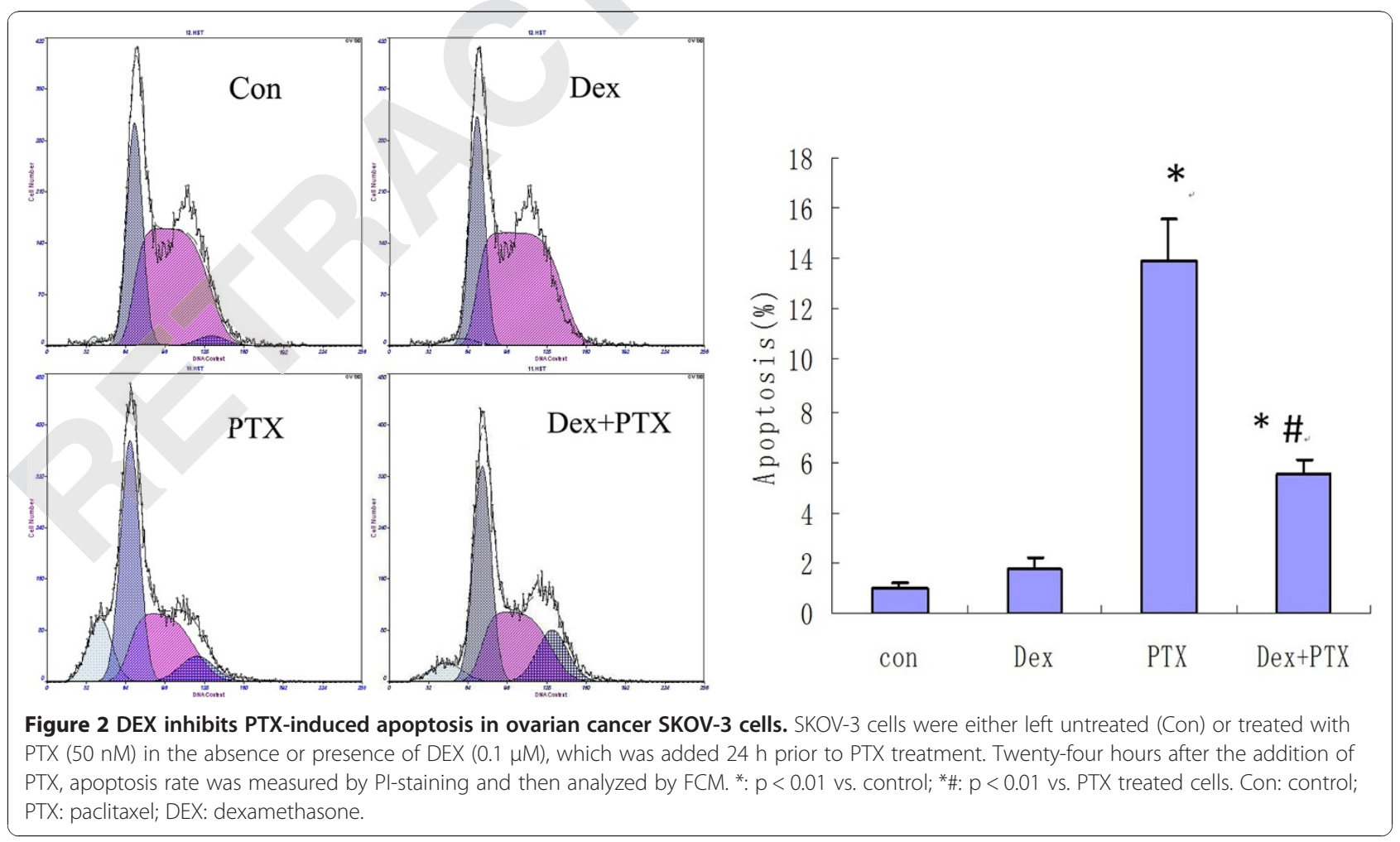




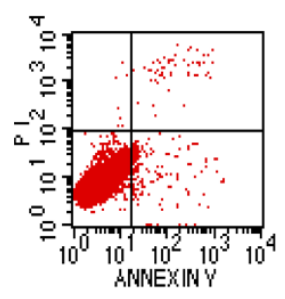

Con

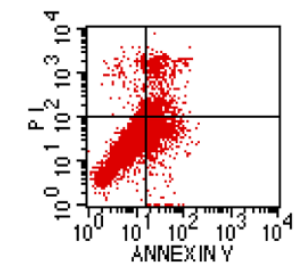

PTX

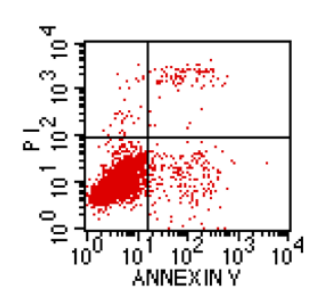

Dex

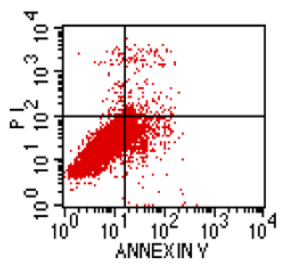

Dex+PTX

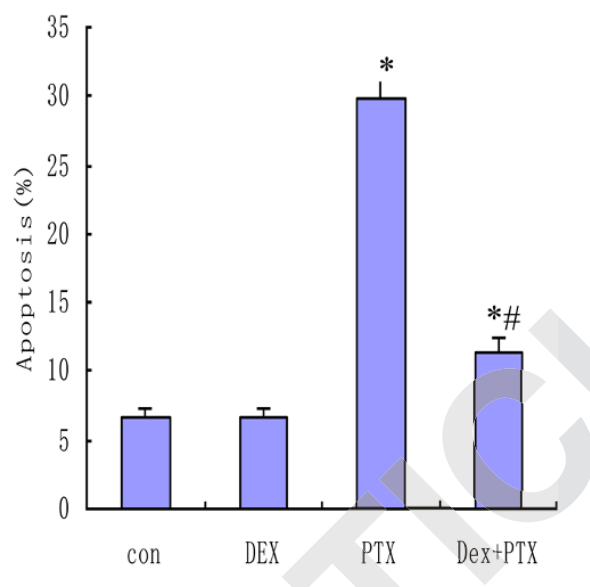

Figure 3 DEX inhibits PTX-induced apoptosis in ovarian cancer H08910 cells. HO8910 cells were either left untreated (Con) or treated with PTX $(50 \mathrm{nM})$ in the absence or presence of DEX pre-treatment $(0.1 \mu \mathrm{M})$. Twenty-four hours following the addition of PTX, apoptosis rate was measured by annexin V-FITC/PI and then analyzed by FCM. *: $p<0.01$ vs. control; *\#: $p<0.01$ vs. PTX treated cells. Con: control; PTX: paclitaxel; DEX: dexamethasone.

Dodecyl Sulfonate), $0.1 \mathrm{~mm} \beta$-mercaptoethanol, containing $2 \mu \mathrm{g} / \mathrm{mL}$ of each of the protease inhibitors: leupeptin, aprotinin, and pepstatin, Sigma Chemical Co., St. Louis, MO) for $10 \mathrm{~min}$. Protein concentrations in cell lysates were measured using the Bio-Rad protein determination assay. Twenty micrograms of protein were separated by
SDS-PAGE, transferred to nitrocellulose membranes (Schleicher and Schuell, Inc., Burlington, VT), and immunoblotted with various primary antibodies. Antibodies to cleaved caspase-3 and Bcl-XL were obtained from Santa Cruz Biotechnology, Inc. (Santa Cruz, CA). The blots were further incubated with conjugated alkaline phosphatase.

\section{B}

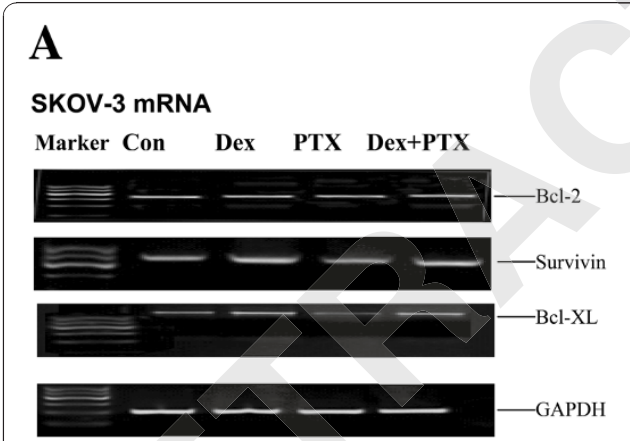

\section{SKOV-3 mRNA}

Bcl-2

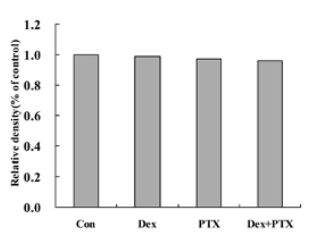

HO-8910 mRNA

\section{HO-8910 mRNA}

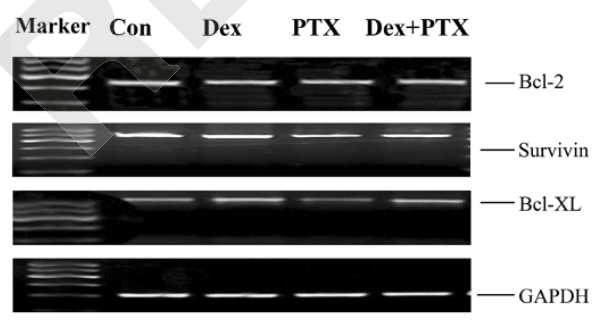

Bcl-2

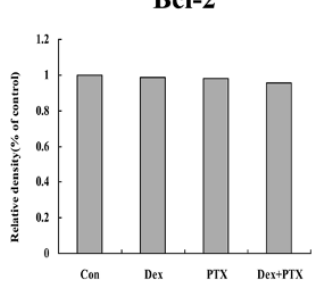

Survivin

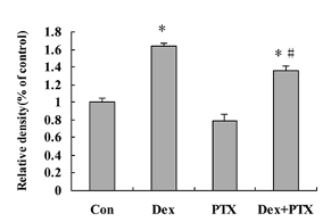

Bcl-XL

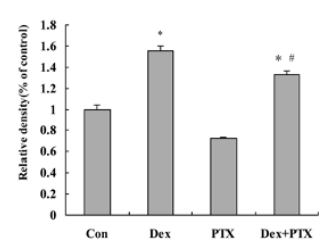

Figure 4 DEX increases the expression of Bcl-XL and survivin but not Bcl-2. SKOV-3 and HO-8910 cells were treated with PTX (50 nM) for $24 \mathrm{~h}$ with or without DEX pre-treatment $(0.1 \mu \mathrm{M})$. The relative expression levels of $\mathrm{BCl}-2$, survivin, and $\mathrm{BCl}-\mathrm{XL}$ (mRNAs) were determined by semi-quantitative RT-PCR. A. PCR results of $\mathrm{BCl}-2$, survivin, and BCl-XL expression. B. Relative expression levels of $\mathrm{BCl}-2$, survivin, and BCl-XL. GAPDH was used as an internal control. *: $p<0.01$ vs. control; *\#: $p<0.01$ vs. PTX-treated cells. PTX: paclitaxel; DEX: dexamethasone. GAPDH: glyceraldehyde-3-phosphate dehydrogenase. 


\section{Statistical analysis}

Statistical analysis was performed using one-way ANOVA (One-factor Analysis of Variance), with Fisher's least significant difference test. Data were expressed as mean \pm SD (Standard Deviation). Differences were considered significant, if $\mathrm{p}<0.05$.

\section{Results}

\section{DEX promotes PTX-induced proliferation}

The effect of DEX on the growth of paclitaxel-induced cells was firstly examined by MTT assay. As shown in Figure 1, the growth of PTX-induced SKOV-3 cells and HO-8910 cells was promoted by DEX in a concentration-dependent manner. These results indicate that DEX can promote the proliferation of PTX-induced SKOV-3 and HO-8910 cells.

\section{DEX prevents PTX-induced apoptosis}

To investigate whether DEX could interfere with apoptosis, we treated SKOV-3 cells in the presence or absence of DEX pre-treatment. Twenty-four hours later, apoptosis was examined by staining of the cells with PI-staining and then analyzed by FCM. The apoptosis rates in human ovarian cancer cell line SKOV-3 induced by PTX, were $5.55 \pm 0.53 \%$ if pre-treated with DEX, and $13.90 \pm 1.62 \%$ if not treated with DEX (p (p value) <0.01) (Figure 2). We treated HO8910 cells in the presence or absence of DEX for $24 \mathrm{~h}$ as well. The apoptosis was examined by staining of the cells with annexin V-FITC/PI and then analyzed by FCM. The percentages of apoptosis in human ovarian cancer cell line HO-8910 induced by PTX, were $11.45 \pm 0.945 \%$ if pre-treated with DEX, and $29.94 \pm 1.49 \%$ if not treated with DEX $(\mathrm{p}<0.01)$ (Figure 3$)$.

DEX pre-treatment increases the expression of $\mathrm{Bcl}-\mathrm{XL}$ and survivin but not $\mathrm{Bcl}-2$ in $\mathrm{HO}-8910$ and SKOV-3 cells

To determine whether anti-apoptotic modulator proteins, such as survivin, a member of the IAP family, and the Bcl-2 and Bcl-XL proteins of the Bcl-2 family were involved in DEX-induced apoptosis inhibition, HO-8910 and SKOV-3 cells were treated with PTX $(50 \mathrm{nM})$ for $24 \mathrm{~h}$ with or without DEX pre-treatment $(0.1 \mu \mathrm{M})$ to examine the expressions of $\mathrm{Bcl}-2, \mathrm{Bcl}-\mathrm{XL}$, and survivin. As shown in Figure 4, the expressions of $\mathrm{Bcl}-\mathrm{XL}$ and survivin mRNAs were significantly up-regulated by the pre-treatment of DEX $(p<0.01)$, whereas the expression of Bcl-2 was un-affected $(\mathrm{p}>0.05)$.

The expression of Bcl-XL protein in SKOV-3 and HO-8910 cells We detected the change of Bcl-XL proteins in SKOV-3 and $\mathrm{HO}-8910$ cells by western blot analysis. As shown in Figure 5, the expressions of Bcl-XL protein were upregulated by DEX pre-treatment in both $\mathrm{HO}-8910$ and SKOV-3 cells $(\mathrm{p}<0.01)$.

\section{The expressions of cleaved caspase- 3 in SKOV-3 and HO-8910 cells}

We detected the change of cleaved caspase- 3 proteins in SKOV-3 and HO-8910 cells by western blot analysis. As

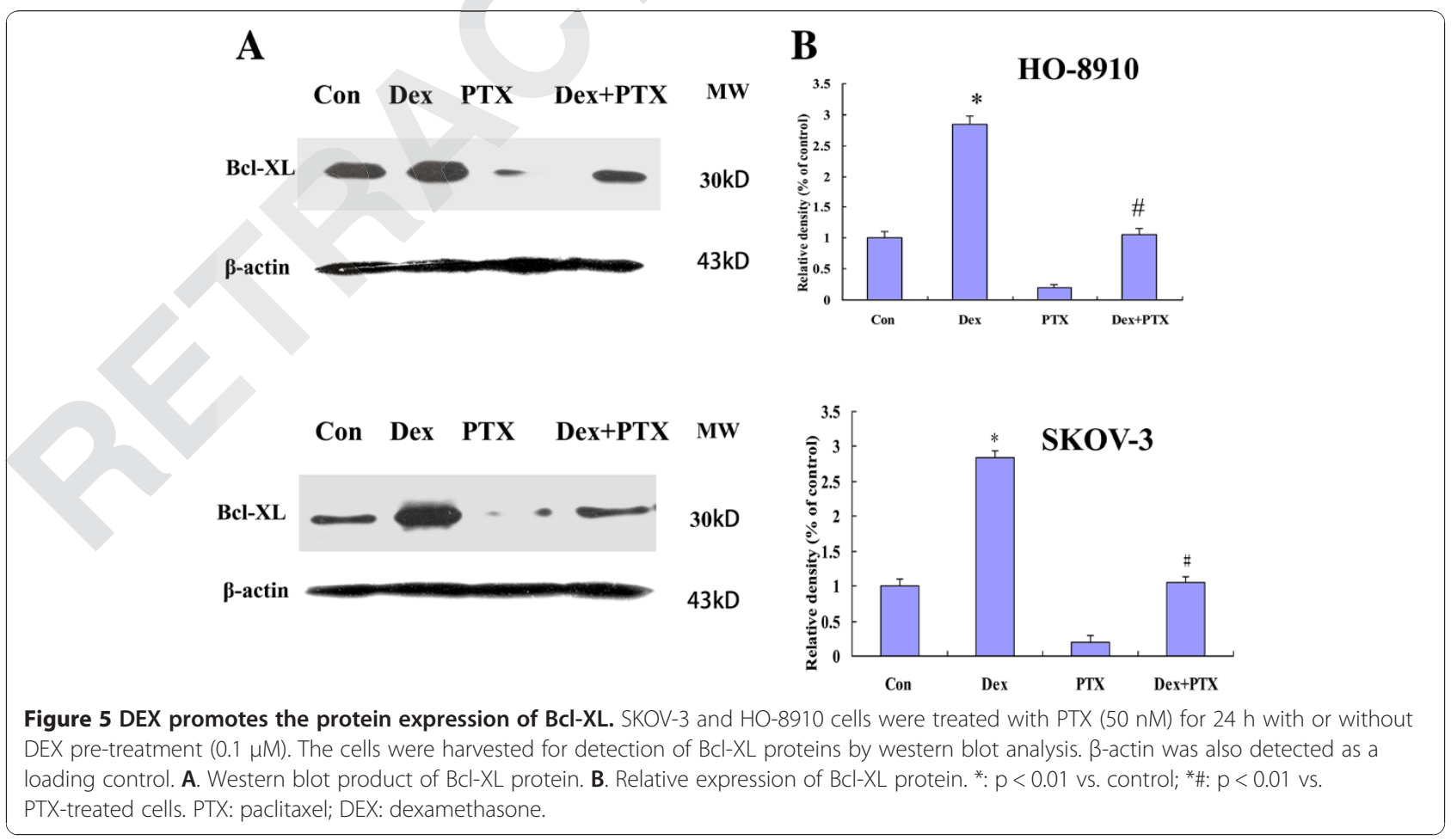




\section{A}

\section{HO-8910}

Con Dex PTX Dex+PTX MW

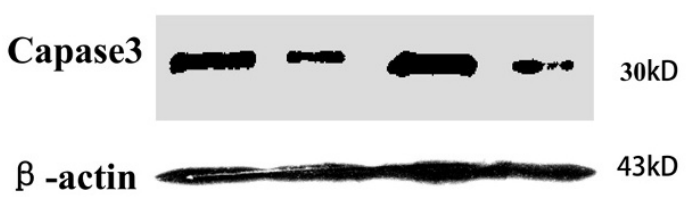

SKOV-3

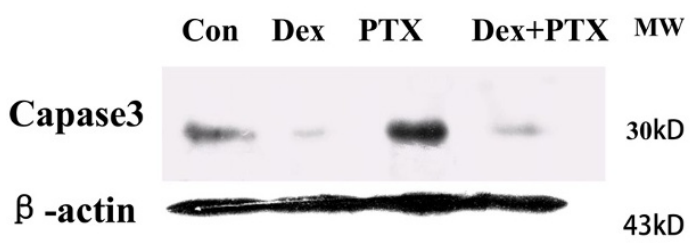

B

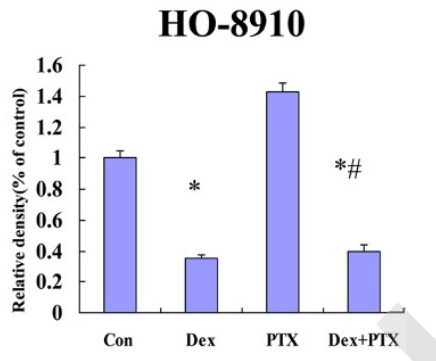

SKOV-3

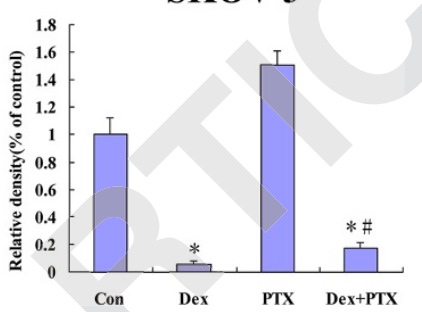

Figure 6 DEX inhibits the expression of cleaved caspase-3 protein. SKOV-3 and HO-8910 cells were treated with PTX (50 nM) for $24 \mathrm{~h}$ with or without DEX pre-treatment $(0.1 \mu \mathrm{M})$. Then, cells were harvested for detection of cleaved caspase-3 protein by western blot analysis. $\beta$-actin was also detected as a loading control. A. Western blot product of cleaved caspase-3 protein. B. Relative expression of cleaved caspase-3 protein. *: $p<0.01$ vs. control; *\#: $p<0.01$ vs. PTX-treated cells. PTX: paclitaxel; DEX: dexamethasone.

shown in Figure 6, the protein expression of cleaved caspase- 3 was down-regulated by DEX pre-treatment in both cancer cell lines $(\mathrm{p}<0.01)$.

\section{Discussions}

DEX has been introduced to tumor therapy because it has potent pro-apoptotic effects on lymphoid cells, thus effective in treating tumor-related edema, inflammation, pain, and electrolyte imbalances [26]. It can also reduce nausea, hyperemesis, and acute toxicity in normal tissue $[16,17]$. However, more and more data have strongly recommended that the application of DEX renders the majority of malignant solid-tumor cells resistant to apoptosis and promotes proliferation following cytotoxic therapy $[27,28]$. In addition, the anti-chemotherapeutic effect of DEX can be seen in anticancer drugs such as cisplatin, 5-fluorouracil, adriamycin, actinomycin D, doxorubicin and gemcitabine $[29,30]$. It has also been known that DEX-induced resistance to chemotherapy agents is through enhancing the anti-apoptotic gene, such as Bcl-XL gene in glioma cells [31,32] and other solid malignant cells [33-35].

In the present study, we demonstrated that DEX may protect human ovarian cancer cell lines HO-8910 and SKOV3 from PTX-induced apoptosis. These findings suggested that the use of DEX can prevent hypersensitivity in the therapy of ovarian cancer, but result in resistance to chemotherapy that reduces tumor growth. Bcl-XL, a member of the $\mathrm{Bcl} 2$ family, is an anti-apoptotic gene on mitochondria. Several transcription factors are present in the Bcl-XL promoter region, such as NF-kB, Stat3, Stat5, and AP-1. DEX has been shown to enhance NF-kB activity in MCF7 breast cancer cells [36]. In contrast, GCs also inhibit PTX-induced apoptosis by inhibition of NF-kB activation $[37,38]$.

Several studies have reported that the inhibitory effect of DEX on the therapeutic activity of PTX seems to be apoptosis-specific because PTX-mediated mitotic arrest or cell cycle distribution was unaffected or marginally affected by the application of steroid [39-41]. By using flow cytometry assays, western blot analysis and RT-PCR, we identified several genes of the death receptor and anti-apoptotic molecule pathways to be influenced by DEX. The expression of Bcl-XL and survivin mRNAs were up-regulated by the pre-treatment of DEX ( $p<0.01)$. However, the mRNA of Bcl-2 mRNA was un-affected by DEX pre-treatment $(p>0.05)$. In term of protein expressions, $\mathrm{Bcl}-\mathrm{XL}$ protein was up-regulated by DEX pre-treatment $(\mathrm{p}<0.01)$. It has been shown, for fibrosarcoma cells, that glucocorticoids can increase the Bcl-XL level by inducing the transcriptional activation of the Bcl-XL promoter [42]. Therefore, one might speculate that the inhibitory effect of DEX on the therapeutic activity of PTX occurs by increasing the expression of anti-apoptotic genes, such as Bcl-XL and survivin.

It is well known that caspase -3 is the effector caspase in apoptosis and can be activated by irradiation, chemotherapeutics, or members of the tumor necrosis factor family [43-46]. Therefore, DEX could resist the PTX-induced expression of key elements of the cell death receptor pathway, such as cleaved caspase-3, in ovarian cancer. 
Our further experiment confirmed that the expression of cleaved caspase-3 was down-regulated by DEX pretreatment $(\mathrm{p}<0.01)$. Intriguingly, down-regulation of these pro-apoptotic genes was not observed in lymphoid cells. This observation is in line with other reports showing the up-regulations of pro-apoptotic genes, such as CD95, caspase-3, and caspase-4, or down-regulations of anti-apoptotic molecules, such as Bcl-2 and Bcl-XL, after DEX treatment in lymphoid cells [47-49]. These pro- and anti-apoptotic effects of DEX might be the reason for its inhibition of apoptosis in carcinoma cells but its activation of apoptosis in lymphoid cells.

It is well known that DEX acts through glucocorticoid receptors (GRs) [50], however, the expressions of GRs were not evaluated in this study. It is a limitation, because only with the knowledge of GRs changes, can the effect of DEX on the cell lines be thoroughly understood.

In conclusion, our data suggested that the application of DEX significantly inhibited the therapeutic activity of PTX in ovarian cancer cells. This result is in contrast to the effect of GCs in lymphoid cells and may involve cell type-specific regulation of survival molecules or antiapoptotic molecules. Thus, our results may provide new evidence that the anti-apoptotic effect of DEX on human ovarian cancer cells is mediated by up-regulating Bcl-XL and surviving, and down-regulating caspase-3 activity. These findings have profound clinical meanings in term of proper application of DEX which might reduce side effects and sacrifice the efficacy of PTX on cancer cell death as well.

\section{Competing interests}

The authors declare that they have no competing interests.

\section{Authors' contributions}

WH and JG participated in the design of this study, and they both performed the statistical analysis. HL carried out the study, together with QD, collected important background information, and drafted the manuscript. YH and RZ conceived of this study, and participated in the design and helped to draft the manuscript. All authors read and approved the final manuscript.

Received: 30 May 2014 Accepted: 31 August 2014

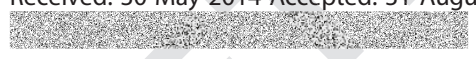

\section{References}

1. Hippisley-Cox J, Coupland C: Identifying women with suspected ovarian cancer in primary care: derivation and validation of algorithm. $\mathrm{Br}$ Med $\mathrm{J}$ 2012, 4:344.

2. Siegel R, DeSantis C, Virgo K, Stein K, Mariotto A, Smith T, Cooper D, Gansler T, Lerro C, Fedewa S: Cancer treatment and survivorship statistics, 2012. CA Cancer J Clin 2012, 62:220-241

3. Rose PG, Blessing JA, Ball HG, Hoffman J, Warshal D, DeGeest K, Moore $\mathrm{DH}$ : A phase II study of docetaxel in paclitaxel-resistant ovarian and peritoneal carcinoma: a Gynecologic Oncology Group study. Gynecol Oncol 2003, 88:130-135.

4. Lorusso V, Giampaglia M, Petrucelli L, Saracino V, Perrone T, Gnoni A: Antiemetic efficacy of single-dose palonosetron and dexamethasone in patients receiving multiple cycles of multiple day-based chemotherapy. Support Care Cancer 2012, 20:3241-3246.

5. Zhang Q, Huang XE, Gao LL: A clinical study on the premedication of paclitaxel liposome in the treatment of solid tumors. Biomed Pharmacother 2009, 63:603-607.
6. Quock J, Dea G, Tanaka M, Gandara D, Lara P, Lau D: Premedication strategy for weekly paclitaxel. Cancer Invest 2002, 20:666-672.

7. Herr I, Ucur E, Herzer K, Okouoyo S, Ridder R, Krammer PH, von Knebel Doeberitz M, Debatin KM: Glucocorticoid cotreatment induces apoptosis resistance toward cancer therapy in carcinomas. Cancer Res 2003, 63:3112-3120.

8. Sui M, Chen F, Chen Z, Fan W: Glucocorticoids interfere with therapeutic efficacy of paclitaxel against human breast and ovarian xenograft tumors. Int J Cancer 2006, 119:712-717.

9. Zhang C, Beckermann B, Kallifatidis G, Liu Z, Rittgen W, Edler L, Buchler P, Debatin KM, Buchler MW, Friess H, Herr I: Corticosteroids induce chemotherapy resistance in the majority of tumour cells from bone, brain, breast, cervix, melanoma and neuroblastoma. Int J Oncol 2006, 29:1295-1301.

10. Zhang C, Kolb A, Buchler P, Cato AC, Mattern J, Rittgen W, Edler L, Debatin KM, Buchler MW, Friess H, Herr I: Corticosteroid co-treatment induces resistance to chemotherapy in surgical resections, xenografts and established cell lines of pancreatic cancer. BMC Cancer 2006, 6:61.

11. Zhang C, Kolb A, Mattern J, Gassler N, Wenger T, Herzer K, Debatin KM, Buchler M, Friess H, Rittgen W, Edler L, Herr I: Dexamethasone desensitizes hepatocellular and colorectal tumours toward cytotoxic therapy. Cancer Lett 2006, 242:104-111.

12. Zhang C, Marme A, Wenger T, Gutwein P, Edler L, Rittgen W, Debatin KM, Altevogt P, Mattern J, Herr I: Glucocorticoid-mediated inhibition of chemotherapy in ovarian carcinomas. Int J Oncol 2006, 28:551-558.

13. Zhang C, Mattern J, Haferkamp A, Pfitzenmaier J, Hohenfellner M, Rittgen W, Edler L, Debatin KM, Groene E, Herr I: Corticosteroid-induced chemotherapy resistance in urological cancers. Cancer Biol Ther 2006, 5:59-64.

14. Gassler N, Zhang C, Wenger T, Schnabel PA, Dienemann H, Debatin KM, Mattern J, Herr I: Dexamethasone-induced cisplatin and gemcitabine resistance in lung carcinoma samples treated ex vivo. Br J Cancer 2005, 92:1084-1088

15. Rutz HP: Effects of corticosteroid use on treatment of solid tumours. Lancet 2002, 360:1969-1970.

16. Rutz HP, Herr I: Interference of glucocorticoids with apoptosis signaling and host-tumor interactions. Cancer Biol Ther 2004, 3:715-718.

17. Hengartner MO: The biochemistry of apoptosis. Nature 2000, 407:770-776.

18. Herr I, Debatin KM: Cellular stress response and apoptosis in cancer therapy. Blood 2001, 98:2603-2614.

19. Krammer PH: CD95's deadly mission in the immune system. Nature 2000, 407:789-795.

20. Das A, Banik NL, Patel SJ, Ray SK: Dexamethasone protected human glioblastoma U87MG cells from temozolomide induced apoptosis by maintaining Bax:Bcl-2 ratio and preventing proteolytic activities. $\mathrm{Mol}$ Cancer 2004, 3:36.

21. Gorman AM, Hirt UA, Orrenius S, Ceccatelli S: Dexamethasone pre-treatment interferes with apoptotic death in glioma cells. Neuroscience 2000, 96:417-425.

22. Ni Chonghaile T, Concannon CG, Szegezdi E, Gorman AM, Samali A: Dexamethasone inhibits apoptosis in $\mathrm{C} 6$ glioma cells through increased expression of Bcl-XL. Apoptosis 2006, 11:1247-1255.

23. Cuevas P, Diaz-Gonzalez D, Sanchez I, Lozano RM, Gimenez-Gallego G, Dujovny M: Dobesilate inhibits the activation of signal transducer and activator of transcription 3, and the expression of cyclin D1 and bcl-XL in glioma cells. Neurol Res 2006, 28:127-130.

24. de Groot RP, Raaijmakers JA, Lammers JW, Koenderman L: STAT5-Dependent CyclinD1 and Bcl-xL expression in Bcr-Abl-transformed cells. Mol Cell Biol Res Commun 2000, 3:299-305.

25. Rahaman SO, Harbor PC, Chernova O, Barnett GH, Vogelbaum MA, Haque SJ: Inhibition of constitutively active Stat 3 suppresses proliferation and induces apoptosis in glioblastoma multiforme cells. Oncogene 2002, 21:8404-8413.

26. Schmidt S, Rainer J, Ploner C, Presul E, Riml S, Kofler R: Glucocorticoid-induced apoptosis and glucocorticoid resistance: molecular mechanisms and clinical relevance. Cell Death Differ 2004, 11(Suppl 1):S45-S55.

27. Wu W, Chaudhuri S, Brickley DR, Pang D, Karrison T, Conzen SD: Microarray analysis reveals glucocorticoid-regulated survival genes that are associated with inhibition of apoptosis in breast epithelial cells. Cancer Res 2004, 64:1757-1764.

28. Wu W, Pew T, Zou M, Pang D, Conzen SD: Glucocorticoid receptor-induced MAPK phosphatase-1 (MPK-1) expression inhibits paclitaxel-associated MAPK activation and contributes to breast cancer cell survival. $J$ Biol Chem 2005, 280:4117-4124 
29. Brenes O, Arce F, Gatjens-Boniche O, Diaz C: Characterization of cell death events induced by anti-neoplastic drugs cisplatin, paclitaxel and 5-fluorouracil on human hepatoma cell lines: Possible mechanisms of cell resistance. Biomed Pharmacother 2007, 61:347-355.

30. Morita M, Suyama H, Igishi T, Shigeoka Y, Kodani M, Hashimoto K, Takeda K, Sumikawa T, Shimizu E: Dexamethasone inhibits paclitaxel-induced cytotoxic activity through retinoblastoma protein dephosphorylation in non-small cell lung cancer cells. Int J Oncol 2007, 30:187-192.

31. Chen DW, Lynch JT, Demonacos C, Krstic-Demonacos M, Schwartz JM: Quantitative analysis and modeling of glucocorticoid-controlled gene expression. Pharmacogenomics 2010, 11:1545-1560.

32. Zhang C, Wenger T, Mattern J, llea S, Frey C, Gutwein P, Altevogt $P$, Bodenmuller W, Gassler N, Schnabel PA, Dienemann H, Marmé A, Hohenfellner M, Haferkamp A, Pfitzenmaier J, Gröne HJ, Kolb A, Büchler P, Büchler M, Friess H, Rittgen W, Edler L, Debatin KM, Krammer PH, Rutz HP, Herr I: Clinical and mechanistic aspects of glucocorticoid-induced chemotherapy resistance in the majority of solid tumors. Cancer Biol Ther 2007, 6:278-287.

33. Gascoyne DM, Kypta RM, Vivanco M: Glucocorticoids inhibit apoptosis during fibrosarcoma development by transcriptionally activating $\mathrm{BCl}-\mathrm{xL}$. J Biol Chem 2003, 278:18022-18029.

34. Wada T, Pippin JW, Marshall CB, Griffin SV, Shankland SJ: Dexamethasone prevents podocyte apoptosis induced by puromycin aminonucleoside: role of p53 and Bcl-2-related family proteins. J Am Soc Nephrol 2005, $16: 2615-2625$

35. Wanke I, Schwarz M, Buchmann A: Insulin and dexamethasone inhibit TGF-beta-induced apoptosis of hepatoma cells upstream of the caspase activation cascade. Toxicology 2004, 204:141-154.

36. Machuca C, Mendoza-Milla C, Cordova E, Mejia S, Covarrubias L, Ventura J, Zentella A: Dexamethasone protection from TNF-alpha-induced cell death in MCF-7 cells requires NF-kappaB and is independent from AKT. BMC Cell Biol 2006, 7:9.

37. Fan W, Sui M, Huang Y: Glucocorticoids selectively inhibit paclitaxel-induced apoptosis: mechanisms and its clinical impact. Curr Med Chem 2004, 11:403-411.

38. Huang Y, Johnson KR, Norris JS, Fan W: Nuclear factor-kappaB/lkappaB signaling pathway may contribute to the mediation of paclitaxel-induced apoptosis in solid tumor cells. Cancer Res 2000, 60:4426-4432.

39. Chen YX, Wang Y, Fu CC, Diao F, Song LN, Li ZB, Yang R, Lu J: Dexamethasone enhances cell resistance to chemotherapy by increasing adhesion to extracellular matrix in human ovarian cancer cells. Endocr Relat Cancer 2010, 17:39-50.

40. Huang $Y$, Fan $W:$ IkappaB kinase activation is involved in regulation of paclitaxel-induced apoptosis in human tumor cell lines. Mol Pharmacol 2002, 61:105-113.

41. Huang $Y$, Fang $Y$, Dziadyk JM, Norris JS, Fan W: The possible correlation between activation of NF-kappaB/lkappaB pathway and the susceptibility of tumor cells to paclitaxel-induced apoptosis. Oncol Res 2002, 13:113-122.

42. Yang N, Zhang H, Si-Ma H, Fu Y, Zhao W, Li D, Yang G: Dexamethasone decreases hepatocellular carcinoma cell sensitivity to cisplatin-induced apoptosis. Hepatogastroenterology 2011, 58:1730-1735.

43. Galon J, Franchimont D, Hiroi N, Frey G, Boettner A, Ehrhart-Bornstein M, O'Shea JJ, Chrousos GP, Bornstein SR: Gene profiling reveals unknown enhancing and suppressive actions of glucocorticoids on immune cells. Faseb J 2002, 16:61-71.

44. Igney FH, Krammer PH: Death and anti-death: tumour resistance to apoptosis. Nat Rev Cancer 2002, 2:277-288.

45. Kaufmann SH, Hengartner MO: Programmed cell death: alive and well in the new millennium. Trends Cell Biol 2001, 11:526-534.

46. Ashkenazi A: Targeting death and decoy receptors of the tumour-necrosis factor superfamily. Nat Rev Cancer 2002, 2:420-430.

47. Chauhan D, Auclair D, Robinson EK, Hideshima T, Li G, Podar K, Gupta D, Richardson P, Schlossman RL, Krett N, Chen LB, Munshi NC, Anderson KC: Identification of genes regulated by dexamethasone in multiple myeloma cells using oligonucleotide arrays. Oncogene 2002, 21:1346-1358.

48. Liu Q, Gazitt Y: Potentiation of dexamethasone-, paclitaxel-, and Ad-p53-induced apoptosis by $\mathrm{Bcl}-2$ antisense oligodeoxynucleotides in drug-resistant multiple myeloma cells. Blood 2003, 101:4105-4114.
49. Schmidt M, Lugering N, Lugering A, Pauels HG, Schulze-Osthoff K, Domschke W Kucharzik T: Role of the CD95/CD95 ligand system in glucocorticoid-induced monocyte apoptosis. J Immunol 2001, 166:1344-1351.

50. Croxtall JD, Choudhury Q, Flower RJ: Glucocorticoids act within minutes to inhibit recruitment of signalling factors to activated EGF receptors through a receptor-dependent, transcription-independent mechanism. Br J Pharmacol 2000, 130:289-298.

doi:10.1186/s13048-014-0089-z

Cite this article as: Hou et al:: The effects of dexamethasone on the proliferation and apoptosis of human ovarian cancer cells induced by paclitaxel. Journal of Ovarian Research 2014 7:89.

\section{Submit your next manuscript to BioMed Central and take full advantage of:}

- Convenient online submission

- Thorough peer review

- No space constraints or color figure charges

- Immediate publication on acceptance

- Inclusion in PubMed, CAS, Scopus and Google Scholar

- Research which is freely available for redistribution 